\title{
HETEROGENEIDADE DISCURSIVA DO/NO ROMANCE VIDAS SECAS: AS VOZES DISCURSIVAS CONSTITUINTES DOS SUJEITOS-FABIANO
}

\author{
VIVIANE DINÊS DE OLIVEIRA RIBEIRO BARTHO ${ }^{1}$ \\ AMANDA MARIA BICUDO DE SOUZA ${ }^{2}$
}

Instituto Federal de São Paulo, campus de Campos do Jordão Rua Monsenhor José Vita, 280, Abernéssia, Campos do Jordão-SP - 12460-000

viviane.barthodifsp.edu.br / viviane dinesdyahoo.com.br

amandadysouza@ifsp.edu.br / amandamarya@yahoo.com.br

Resumo. A visão de língua apenas enquanto sistema de signos com sentido imanente limita a leitura crítica. Reservar ao texto literário a propriedade da pluralidade de sentido, restrita à conotação e à ambiguidade estilística, não é suficiente. Torna-se necessário compreender a língua como semanticamente opaca, em que o interdiscurso incide sobre os efeitos de sentidos. A concepção de sujeito também se altera para a de sujeito cindido, heterogêneo e atravessado pelo inconsciente. Assim, objetiva-se analisar o romance "Vidas Secas", de Graciliano Ramos, à luz da Análise do Discurso Francesa, a fim de se propor uma leitura crítica da constituição discursiva e, portanto, ideológica, de sujeitos sócio-históricos, representados mimeticamente pela personagem Fabiano, de existência fictícia.

Palavras-chave: heterogeneidade; constituição do sujeito; língua e discurso; "Vidas Secas"; texto literário.

\begin{abstract}
The comprehension of language only as a system of signs with immanent sense limits the critical reading. It is not enough to reserve to the literary text the property of plurality of meaning, restricted to stylistic connotation and ambiguity. It becomes necessary to understand the language as semantically opaque, in which interdiscourse focuses on the effects of meanings. The conception of the subject also changes to that of a split, heterogeneous subject, passed by the unconscious. Thus, the objective is to analyze the novel "Vidas Secas", by Graciliano Ramos, in the light of the French Discourse Analysis, in order to propose a critical reading of the discursive and therefore ideological constitution of socio-historical subjects, represented mimetically by the character Fabiano, of fictitious existence.
\end{abstract}

Keywords: heterogeneity; constitution of the subject; language and discourse; "Vidas Secas"; literary text.

\footnotetext{
${ }^{1}$ Doutoranda em Letras pela Universidade de São Paulo.

2 Doutoranda em Ciências da Linguagem pela Universidade do Vale do Sapucaí.
} 


\section{INTRODUÇÃO}

Há uma visão comum e equivocada de que a opacidade da língua seja um fenômeno que ocorra apenas em textos literários, ficcionais, e que a linguagem cotidiana ou empregada em enunciados não literários, como da esfera jornalística, científica ou jurídica, apresenta uma transparência em relação à sua significação. É uma visão ainda muito marcada pela compreensão de língua enquanto sistema de signos, advinda, sobretudo, de estudos saussurianos, cuja atenção se voltava para a estrutura linguística, sem observação aos falantes, bem como aos contextos de produção da enunciação ${ }^{3}$.

Diante dessa visão de língua / linguagem, a leitura e a escrita são, muitas vezes, desenvolvidas pelos professores de modo a fechar sentidos, apontar um caminho unívoco de compreensão, dando tratamento aos textos como se tivessem significação imanente, a qual seria desvelada pelo leitor-aluno e "mostrada" ao professor, o qual teria a capacidade (e o poder) de averiguar se a compreensão "descoberta" corresponde, de fato, ao que o autor, deliberadamente, quis transmitir (CORACINI, 2010). Essa situação se concretiza em perguntas do tipo: $O$ que o autor do texto quis dizer?.

Atitudes ou posturas de leitura como essas, em relação a textos verbais e não verbais, são insuficientes por desconsiderarem a relevância dos sujeitos no processo interpretativo e por transmitirem a ideia de que a língua é mero instrumento ou ferramenta, que está fora dos sujeitos e da história e que pode ser manipulada, controlada, de forma consciente (CORRÊA, 2016).

Pensando, especificamente, na leitura do texto literário: quando se considera algum grau de opacidade da linguagem artística, essa característica fica, frequentemente, no campo da conotação e da ambiguidade estilística, como se fosse próprio apenas da literatura o fato de os signos linguísticos evocarem mais de uma significação, a qual, no entanto, continua, muitas vezes, engessada por um rol de possibilidades já previsto pelo professor / avaliador que encara os sentidos como "escondidos" pelo autor, podendo, assim, serem "decifrados".

Acreditamos que a leitura em sala de aula poderia ser mais crítica e que os alunos poderiam ter uma relação menos ingênua com a linguagem se ela fosse (re)conhecida segundo os efeitos de sentido que pode apresentar. Não é, no entanto, o que comumente acontece em sala de aula. Para um avanço nessa questão, a visão de linguagem dos professores, em geral, e de língua, em particular, deveria considerar aspectos que a ela escapam, por serem históricos e inconscientes, principalmente depois da relevância de muitas teorias linguísticas e estudos sobre a linguagem, como as reflexões de Benveniste sobre a subjetividade na linguagem; as de Bakhtin sobre ideologia e valores axiológicos que constituem os signos linguísticos; as de Pêcheux sobre os discursos sócio-históricoideológicos, que, por meio da memória discursiva, são resgatados e materializados nos

\footnotetext{
${ }^{3}$ Segundo Courtine (2006, p. 59), com Saussure, "a linguística se tornou uma linguística da linguagem, excluindo o sujeito falante e, portanto, o discurso produzido por este sujeito". Não fazemos aqui crítica a Saussure e a seus estudos; pelo contrário, reconhecemos sua importância à Linguística. Apenas ressaltamos, nesta introdução ao tema em questão, qual era seu interesse de pesquisa. Outros estudos posteriores observaram a necessidade de ampliação do olhar saussuriano e expandiram as teorias linguísticas de diferentes formas.
} 
enunciados; entre muitos outros estudos. Para o presente artigo, propomos que a leitura poderia ser leitura de discursos que constituem um texto (literário e não literário), sempre em processo de interdiscurso.

A partir do exposto, este trabalho objetiva analisar um recorte discursivo do romance "Vidas Secas", de Graciliano Ramos, de forma a rastrear possíveis discursos materializados na obra que apontem para a sua heterogeneidade inerente (AUTHIERREVUZ, 1990, 2004). Ao tecer um olhar à heterogeneidade discursiva, evocam-se uma concepção de língua sócio-histórica e ideológica, semanticamente opaca, e uma concepção de sujeito fragmentado, cindido, contraditório e atravessado pelo inconsciente.

Para além de uma leitura que leve em conta a conotação e a ambiguidade estilística, como características únicas que engendrariam a opacidade da língua, acreditamos que a leitura analítica, pelo viés discursivo, da obra "Vidas Secas" contribui para um modo de leitura mais crítico, a fim de buscar os efeitos de sentido que os discursos podem construir em dado contexto de interação enunciativa.

Teoricamente, a análise tomará como norteadores conceitos da Análise do Discurso Francesa (AD), de modo a interpretar a constituição heterogênea da obra delimitada, bem como da personagem protagonista, que reflete, de modo mimético, os sujeitos sociais de existência empírica. A organização do trabalho será a seguinte: 1. Língua, Sujeito e Discurso; 2. Interdiscurso e Heterogeneidade discursiva; 3. Vidas Secas: autor, enredo, características; 4 . Análise da heterogeneidade discursiva da/na obra.

\section{LÍNGUA, SUJEITO E DISCURSO}

A noção de "sujeito" na AD, a partir das ideias de Pêcheux, está indissociável da noção de "discurso", uma vez que se funda no pressuposto de que não existe discurso sem sujeito. E, como o discurso é o objeto de estudo da $\mathrm{AD}$, faz-se necessário discutir a relação entre essas noções básicas.

Para Pêcheux (1988), a subjetivação é o processo pelo qual o indivíduo torna-se sujeito ao ser interpelado pela ideologia. As ideologias materializam-se em práticas e manifestam-se nos discursos que, por sua vez, constituem os sujeitos à medida que estes assumem posições sócio-históricas (posição-professor, posição-polícia, posição-patrão etc.) na sociedade. Os sujeitos assumem posições sob a impressão de o fazerem por um processo natural, de livre vontade, quando são, na verdade, conduzidos a tal assim que começam a participar do funcionamento do sistema social, que é ideológico, passando a representar, de forma imaginária, suas condições de existência, alienando-se delas. Essa alienação que se faz pelo imaginário é tal que se reproduz a seguinte distorção: em lugar de as instituições servirem aos sujeitos, são eles que servem a elas (CASTORIADIS, 1995 apud UYENO, 2012).

A partir disso, o sujeito passa a ser constituído por discursos que estão em circulação no momento histórico, ou seja, que estão na "ordem do discurso", legitimados socialmente numa dada época (FOUCAULT, 1996). Discurso pode ser entendido como o efeito de sentido entre os interlocutores; encontra-se no social; é exterior à língua, porém 
dela precisa para se manifestar, ou seja, o discurso diz respeito a aspectos sociais e ideológicos que se impregnam nas palavras e nas práticas dos sujeitos para se materializar (PÊCHEUX, 1988).

Os discursos remetem a formações ideológicas, conjunto de ideologias, que se manifestam em formações discursivas, conceituadas como aquilo que "determina $o$ que pode e deve ser dito (articulado sob a forma de uma arenga, de um sermão, de um panfleto, de uma exposição, de um programa, etc.)" (PÊCHEUX, 1988, p. 160); além disso, são as formações discursivas que determinam os sentidos das palavras, textos, posições, o que permite compreender, por exemplo, que a palavra "mulher", em um dado contexto, pode produzir diferentes sentidos conforme a formação discursiva à qual o sujeito estaria filiado. Esses efeitos de sentido podem apontar, consequentemente, ideologias machistas, feministas, religiosas e outras tantas.

Os discursos, que fazem parte de formações ideológicas e discursivas, não são propriamente textos ou falas, mas, sim, efeitos de sentido materializados em palavras, textos, signos linguísticos, ou seja, os discursos relacionam-se a aspectos sócio-históricoideológicos e precisem da língua para se manifestar. Assim, segundo Orlandi (2005, p. 43), “[...] O estudo do discurso explicita a maneira como linguagem e ideologia se articulam, se afetam em sua relação recíproca”.

Todo esse processo de produção de sentido é realizado por meio de dois tipos de esquecimentos pelos quais os sujeitos são afetados para se constituírem como tais e para enunciarem (PÊCHEUX, 1988): o esquecimento denominado de número 1 está relacionado às escolhas particulares dos sujeitos para produzir enunciados com a ilusão de controle da produção dos sentidos sobre aquilo que enuncia; já o esquecimento denominado de número 2 é aquele que leva o sujeito a enunciar sob a ilusão de ser a fonte dos dizeres, a origem dos discursos.

\section{INTERDISCURSO E HETEROGENEIDADE DISCURSIVA}

Os discursos são retomados, conforme as regras das formações discursivas a que pertencem, e relacionados numa espécie de rede ou emaranhado por meio de processos denominados interdiscursos. Em outras palavras, o interdiscurso é a retomada, sob efeitos do esquecimento de número 2 , de discursos já produzidos, já existentes anteriormente, o que permite a conclusão de que todo discurso é constituído de outros discursos, e, por conseguinte, todo dizer é constituído de outros dizeres (PÊCHEUX, 1988).

Pêcheux (1988) explica, ademais, que o interdiscurso sofre uma linearização, sob efeitos do esquecimento de número 1, no eixo do intradiscurso, que é "o funcionamento do discurso com relação a si mesmo (o que eu digo agora, com relação ao que eu disse antes e ao que eu direi depois; portanto, o conjunto dos fenômenos de 'co-referência' que garantem aquilo que se pode chamar o 'fio do discurso', enquanto discurso de um sujeito)" (PÊCHEUX, 1988, p. 166). E ainda, o intradiscurso só é entendido, quando se compreende sua relação com o interdiscurso, ou seja, uma produção discursiva materializada em enunciados ganha sentido quando os sujeitos entendem o interdiscurso formado. 
O sujeito retoma discursos passados, sob a ilusão de autonomia devido ao esquecimento 2, ao mesmo tempo em que é afetado pela ressonância de vozes de uma memória discursiva. Paradoxalmente, os processos de esquecimento e de memória agem inconscientemente sobre os sujeitos para que possam enunciar e constituir-se como tais (COURTINE, 1999 apud GREGOLIN, 2001; UYENO, 2011).

O sujeito é constituído de diferentes discursos, originários de diferentes formações ideológicas, o que faz dele um sujeito heterogêneo e, por vezes, contraditório. Em outros termos, a heterogeneidade faz-se, pois, pela alteridade, pelo discurso do outro. Segundo Teixeira (1997), elucidando acerca da subjetivação na teoria de Pêcheux, o indivíduo é interpelado em sujeito por meio do discurso, ou melhor, pela formação discursiva que representa, na linguagem, as formações ideológicas. Na superfície discursiva, irrompe o pré-construído, que impõe como sempre-já lá, ou seja, que se impõe como sentido universal. O sujeito, por sua vez, sofre a interpelação como causa de si, isto é, o indivíduo é interpelado em sujeito ao mesmo tempo em que já é sujeito, constituído a partir de uma rede de significantes com existência antes e fora do próprio sujeito. Os esquecimentos 1 e 2 operam no acobertamento da causa do sujeito; logo, ele se constitui pelo esquecimento do que o determina. O processo de subjetivação ocorre, dessa forma, a partir de um exterior que oferece ao sujeito a ilusão de unidade e coerência. É a ideologia que fornece as evidências de sentido, mascaradas pela ilusão de transparência da linguagem (TEIXEIRA, 1997). O "eu" se percebe homogêneo e consciente dos sentidos que interpreta como sendo originalmente seus, quando, na verdade, é um sujeito perpassado por discursos históricos e culturais que, por vezes, contradizem-se. O sujeito é, em sua essência, heterogêneo.

Authier-Revuz (2004) define dois tipos de heterogeneidade: a constitutiva e a mostrada. A primeira diz respeito à natureza de todo sujeito, já que todo sujeito é heterogêneo, dada a forma como ocorre sua constituição, perpassada por discursos harmoniosos e conflitantes. A segunda é a heterogeneidade explícita nos textos produzidos, ao se fazer referência a ideias de outros sujeitos, ao se sinalizarem pensamentos alheios com aspas ou com outra marca formal.

Embora, ao enunciar, o sujeito busque e empregue mecanismos linguísticos de coesão e coerência, que deixem o texto verbal (oral ou escrito) com aparência homogênea em sua superfície e que pareçam "apagar" sua heterogeneidade, ela sempre escapa e pode ser interpretada por uma análise discursiva.

\section{VIDAS SECAS: AUTOR, ENREDO, CARACTERÍSTICAS}

Graciliano Ramos nasceu em 27 de outubro de 1892, na cidade de Quebrangulo, em Alagoas. Em 1914, mudou-se para o Rio de Janeiro e começou a trabalhar como revisor dos jornais "Correio da Manhã" e "A Tarde". Fez sua estreia na literatura em 1933, com o romance "Caetés". Na sequência, em 1934, publicou o romance "São Bernardo" e "Angústia", em 1936. Nesse ano, o escritor foi preso pela acusação de subversão e participação em movimento comunista, que era perseguido na época. Após percorrer vários presídios, foi libertado em janeiro de 1937. A narrativa da vivência desse 
período resultou no livro "Memórias do Cárcere". Após essa publicação, veio o romance "Vidas Secas", escrito em 1938, considerado sua obra mais importante.

As personagens de "Vidas Secas" são construídas, dentro do contexto do enredo, como sujeitos que vivem em estado de miséria e são retirantes do sertão nordestino. Fugindo da seca, Fabiano, protagonista; a esposa, Sinhá Vitória; os filhos, menino mais novo e menino mais velho; e uma cachorra, chamada Baleia, saem em marcha penosa sob um sol escaldante.

A história inicia-se com o capítulo "Mudança", quando a família, em caminhada por vários dias, procura um lugar em que haja as condições mínimas para a sobrevivência. A narrativa é cortante, transmitindo o cansaço, a pobreza, a fome, a sede, a falta de perspectivas do grupo. De repente, aparecem juazeiros e uma fazenda abandonada. Assim que lá chegam, começa a chover. Fabiano instala-se com a família na casa, mas surge o patrão, que quer expulsá-lo, dizendo-se dono daquele local. Fabiano apresenta-se como vaqueiro; o fazendeiro, então, entrega-lhe os ferros de marcar gado e aceita que o retirante trabalhe na terra, em troca de parte dos animais dos quais cuidará, de um pedaço de terreno para plantar e da casa velha para ficar com a esposa e os filhos. O trabalho é praticamente escravo, incerto. O patrão fala em juros, e Fabiano nunca consegue alcançar uma situação favorável que pudesse oferecer a ele e à família uma vida mais digna.

Ao longo dos treze capítulos, são narrados acontecimentos de pequenas alegrias e fatos de muita tristeza, como a morte da cachorra Baleia, humanizada e caracterizada como um ente da família. Chega o tempo de nova estiagem, e Fabiano pensa em nova retirada. O último capítulo, "Fuga", portanto, narra a família enfrentando mais uma marcha sob o sol e pela seca, em busca de um outro lugar em que pudesse se instalar e viver. O romance apresenta um enredo cíclico, acompanhando o ciclo da seca, que castiga tantos sertanejos do nordeste brasileiro.

Como literatura é mimese, imitação da realidade, não podemos tomá-la como a verdade, a própria realidade, mas, sim, como uma representação dessa realidade (PROENÇA FILHO, 2007), apresentando-nos posições-sujeito e discursos que as constituem, de forma verossímil. Isso, consequentemente, acaba por nos falar muito sobre nossa estrutura social real ${ }^{4}$.

Neste artigo, pretendemos fazer uma leitura discursiva do romance "Vidas Secas", mais especificamente do capítulo "Contas". Observando os mecanismos linguísticos, os recursos literários e a construção artística empreendida pelo autor, podemos ler criticamente os discursos materializados e tecer uma interpretação sobre a constituição heterogênea e contraditória de sujeitos sociais representados pelo sujeito fictício Fabiano.

\footnotetext{
4 Aqui, não nos referimos ao "Real" pecheutiano, do "impossível” (PÊCHEUX, 1990), mas, sim, ao emprego ordinário da palavra, como antônimo daquilo que seria ficção ou fabulação.
} 


\section{ANÁLISE DA HETEROGENEIDADE DISCURSIVA DA/NA OBRA}

O enredo desenvolve-se em $3^{a}$ pessoa, com narrador-onisciente ${ }^{5}$. A construção da personagem Fabiano ocorre a partir da condição social de pobreza de um retirante do sertão nordestino brasileiro que, sem estudo, vende sua mão de obra quase de maneira escrava, trabalhando por alimento e moradia à família. Com o retorno dos períodos prolongados e miseráveis de estiagem, Fabiano lança-se com a mulher e os dois filhos a mais uma jornada, caminhada, fuga da seca.

Nota-se, no decorrer do livro, que o protagonista tem poucas falas em discurso direto, isso reforça a pobreza, não só socioeconômica da personagem, mas a pobreza de linguagem, que seria um recurso importante para se fazer frente à luta social. No entanto, Graciliano Ramos consegue enredar o leitor aos pensamentos de Fabiano, às suas possíveis respostas aos outros, às suas vozes constitutivas, de modo que é possível "escutar" a personagem, como ela percebe o mundo, como entende a si própria, como explica o que lhe ocorre. Como é possível escutar a personagem sem que ela fale? Fabiano torna-se uma personagem complexa, na qual se instalam discursos sociais: discursos não do autor, de existência empírica; não de Fabiano, como sujeito individual de existência fictícia; mas discursos de classe sócio-historicamente construídos e que constituem sujeitos sociais, representados por Fabiano. E isso é, artisticamente, elaborado na obra.

Fabiano é, na história ficcional, um homem de poucas palavras (não por personalidade, mas por condição), o que lhe limita em relação ao desenvolvimento do discurso direto e indireto. A construção dessa personagem apenas pela voz do narrador poderia perder a eficácia ou convencimento sobre a denúncia social claramente pretendida na obra. Poderia, ainda, aproximar-se da opinião pessoal, de um olhar particular, que minimizaria o engajamento político do autor com sua arte. É, portanto, por meio do discurso indireto livre ${ }^{6}$ que Graciliano Ramos nos revela não só o sertanejo com suas características físicas, costumes e contextos de vida típicos, mas a constituição discursiva e ideológica que domina essa figura e a subjuga. Esse recurso, do discurso indireto livre, ganha, pois, um caráter engajado a uma crítica social que denuncia as desigualdades e os artifícios que as classes mais abastadas usam para se manter no poder.

No presente artigo, delimitou-se o capítulo "Contas", do romance "Vidas Secas", para se tecer uma análise dos discursos; discursos estes que se materializam em vozes sociais, as quais, na obra, são ouvidas por meio do discurso indireto livre, ou seja, na

\footnotetext{
${ }^{5} \mathrm{O}$ narrador-personagem, com focalização em $1^{\mathrm{a}}$ pessoa, participa da história, sendo uma personagem dela. $\mathrm{O}$ narrador-observador, com focalização em $3^{\mathrm{a}}$ pessoa, limita-se a descrever personagens e a narrar a história, do exterior, sem dela participar. O narrador-onisciente, também com focalização em $3^{\mathrm{a}}$ pessoa, tem aspecto privilegiado, pois narra não só o que observa, mas também o íntimo das personagens, o que sentem e pensam (TERRA, 2014).

${ }^{6}$ No discurso indireto livre, ocorre uma espécie de fusão, em que o narrador, em vez de reproduzir as próprias palavras da personagem, por meio do discurso direto, ou de informar o leitor sobre o que ela teria dito, por meio do discurso indireto, aproxima-se da personagem e confunde-se com ela, transmitindo a impressão de que ambos falam. Assim, às vezes, torna-se um pouco difícil separar a fala da personagem do discurso do narrador. Essa fronteira entre os dois é possibilitada pela liberdade que o narrador tem em relação ao emprego dos recursos formais de escrita, como aspas, travessão, verbos de elocução. Em outras palavras, o narrador, em sua onisciência e envolvimento com o enredo, não faz distinção formal entre sua narração e a fala das personagens, provocando um misto entre elas, deixando pouco claro para o leitor de quem seria a voz (GARCIA, 1988).
} 
fronteira tênue, embaçada, entrecruzada, em que se encontram a enunciação do narrador e a da personagem.

Ao longo da leitura do capítulo "Contas", podem-se compreender discursos dominantes e conservadores que se filiam a uma formação discursiva muito presente na visão que as classes privilegiadas têm sobre o pobre. A ideia de que ser rico e ser pobre é algo predestinado (com ligações a discursos medievais de predestinação divina) e a ideia de que a ascensão social é impossível perpassam séculos, com a dominação da nobreza, do clero e, posteriormente, da burguesia. É um discurso apaziguador, que busca conformar (e confortar) as classes miseráveis por meio da naturalização da pobreza e da legitimação dos supostos motivos que levam uns a deterem privilégios sobre outros (SOUZA, 2015). Trechos do início do capítulo "Contas" possibilitam a compreensão do que é refletido:

Fabiano recebia na partilha a quarta parte dos bezerros e a terça dos cabritos. Mas como não tinha roça e apenas se limitava a semear na vazante uns punhados de feijão e milho, comia na feira, desfazia-se dos animais, não chegava a ferrar um bezerro ou assinar a orelha de um cabrito.

Se pudesse economizar durante alguns meses, levantaria a cabeça. Forjara planos. Tolice, quem é do chão não se trepa. Consumidos os legumes, roídas as espigas de milho, recorria à gaveta do amo, cedia por preço baixo o produto das sortes. [...].

(RAMOS, 1995, p. 92; grifo nosso)

O primeiro parágrafo apresenta a situação de pobreza de Fabiano e sua família. No segundo, já há indícios da voz de Fabiano ([...] Forjara planos. Tolice, quem é do chão não se trepa.) por meio do discurso indireto livre, revelando sua constituição de alienação ao discurso de uma classe social que não é a sua, mas que o domina. A linguagem figurada em "quem é do chão não se trepa" pode ser entendida como "quem é pobre assim sempre será".

Em outra passagem, também se observa esse discurso:

[...] Pois não estavam vendo que ele era de carne e osso? Tinha obrigação de trabalhar para os outros, naturalmente, conhecia o seu lugar. Bem. Nascera com esse destino, ninguém tinha culpa de ele haver nascido com um destino ruim. Que fazer? Podia mudar a sorte? Se lhe dissessem que era possível melhorar a situação, espantar-se-ia. Tinha vindo ao mundo para amansar brado, curar feridas com rezas, consertar cercas de inverno a verão. Era sina. O pai vivera assim, o avô também. E para trás não existia família. Cortar mandacaru, - aquilo estava no sangue. Conformava-se, não pretendia mais nada. Se lhe dessem o que era dele, estava certo. Não davam. Era um desgraçado, era como um cachorro, só recebia ossos. [...]. (RAMOS, 1995, p. 96)

Esse trecho transcrito está todo elaborado em discurso indireto livre: por um lado, claramente se nota a fala da personagem Fabiano, seu tom de desespero, seus sentimentos; por outro, há referenciação em terceira pessoa ([...] Pois não estavam vendo que ele era de carne e osso? [...]), o que leva o leitor a entender o trecho como a narração do narrador- 
onisciente sobre a cena. Não há indicações formais que permitam estabelecer uma diferenciação exata entre o que é dito pelo narrador e o que é dito por Fabiano. As interrogações revelam indignação, revolta da personagem que, na ocasião transcrita, acabara de ser extorquido, enganado, feito de tolo por seu patrão.

As afirmações categóricas, como "Tinha obrigação de trabalhar para os outros, naturalmente, conhecia o seu lugar. Bem.", "Tinha vindo ao mundo para amansar brado, curar feridas com rezas, consertar cercas de inverno a verão. Era sina. O pai vivera assim, o avô também" parecem crenças de Fabiano sobre si mesmo, e não uma descrição do narrador sobre a personagem. E essas crenças, essa visão de si, do mundo, das situações da história... são naturalizadas discursivamente, constituindo o sujeito representado por Fabiano; sujeito este que não consegue compreender de outra forma sua condição social e reproduz, pela memória discursiva, um discurso dominante de que os indivíduos nascem predestinados à pobreza ou à riqueza, sendo difícil ou impossível a ascensão social. É esse mesmo discurso que legitima a extorsão do patrão sobre Fabiano.

O interdiscurso constitui a personagem e os sujeitos - de existência empírica e individual, mas também, e aqui principalmente, de existência sócio-histórica e ideológica. Esse resgate discursivo de sentidos construídos, que se opera pela memória discursiva, torna a todos nós heterogêneos e cindidos, embora enunciemos sob ilusão de unidade, centro, homogeneidade, coerência. Pelos esquecimentos 1 e 2, materializamos no intradiscurso o interdiscurso e trazemos à tona a estrutura - o sentido pré-construído e sedimentado historicamente - no acontecimento, na enunciação realizada sob outras condições de produção e, portanto, no novo (PÊCHEUX, 1990). Graciliano Ramos, apesar de não ter sido linguista, parece ter percebido esses processos discursivos que explicam, em certa medida, o assujeitamento da personagem Fabiano - um sujeito submetido aos efeitos de sentido que o dominam e o filiam a uma formação ideológica que não contribui para a melhora de suas próprias condições socioeconômicas.

Fabiano era um sertanejo em situação de miséria submetido ao discurso dominante do patrão; discurso este que conforma (e conforta) o oprimido em sua condição subjugada. A concepção que Fabiano tem do pobre o coloca, inconscientemente, em posição humilhante. Leiamos o seguinte trecho:

Aí Fabiano baixou a pancada e amunhecou. Bem, bem. Não era preciso barulho não. Se havia dito palavra à-toa, pedia desculpa. Era bruto, não era ensinado. Atrevimento não tinha, conhecia o seu lugar. Um cabra. Ia lá puxar questão com gente rica? Bruto, sim senhor, mas sabia respeitar os homens. Devia ser ignorância da mulher, provavelmente deveria ser ignorância da mulher. Até estranhara as contas dela. Enfim, como não sabia ler (um bruto, sim senhor), acreditara na sua velha. Mas pedia desculpa e jurava não cair noutra.

O amo abrandou, e Fabiano saiu de costas, o chapéu varrendo o tijolo, $[\ldots]$.

Foi até a esquina, parou, tomou fôlego. Não deviam tratá-lo assim. Diante da bodega de seu Inácio virou o rosto e fez uma curva larga. Depois que aconteceu aquela miséria, temia passar ali. Sentou-se numa calçada, tirou do bolso o dinheiro, examinou-o, procurando adivinhar quanto the tinham furtado. Não podia dizer em voz alta que aquilo era um furto, mas era. Tomavam-lhe o gado quase de graça e 
ainda inventavam juro. Que juro! O que havia era safadeza. [...]. (RAMOS, 1995, p. 93-94)

Não se pode dizer que Fabiano não tinha consciência nenhuma do que o patrão lhe fizera; a divergência de cálculos que configurou o roubo na hora de acertar as contas no fim do mês se confirma em: "Sentou-se numa calçada, tirou do bolso o dinheiro, examinou-o, procurando adivinhar quanto lhe tinham furtado. Não podia dizer em voz alta que aquilo era um furto, mas era". No entanto, esse conhecimento não garante mudança de atitude do sertanejo, não o habilita a procurar meios de fazer valer seus direitos, uma vez que se constitui de sentidos que foram naturalizados e legitimados para "colocar o pobre em seu devido lugar, em posição de obediência", como se o outro, o dominante, tivesse a permissão por direito (natural ou divino) de ser quem é e fazer o que faz. A sedimentação desse discurso da classe dominante é apresentada na obra por meio do recurso do discurso indireto livre, em que Fabiano parece dizer: "Era bruto, não era ensinado. Atrevimento não tinha, conhecia o seu lugar. Um cabra. Ia lá puxar questão com gente rica? Bruto, sim senhor, mas sabia respeitar os homens". A personagem enuncia estabelecendo a divisão de classe e seu pertencimento à classe desfavorecida: "conhecia seu lugar". Faz pressupor o contraponto entre "gente rica" e "eu, pobre". Conforme a concepção frequente das classes dominantes sobre o pobre, Fabiano caracteriza-se como "bruto, não ensinado, um cabra", ou seja, sem conhecimento, sem educação, sem inteligência. Aliás, essa é, muitas vezes, a justificativa para se explicar a condição de pobreza: por não se ter educação, é-se pobre. Em outra passagem, é empregado o operador discursivo "mas", opondo "sou bruto" e "sei respeitar os homens". Nessa oposição, Fabiano coloca-se como "bruto", mais próximo a um animal não ensinado, enquanto o outro, no caso, o patrão, é visto como "homem". Logo, Fabiano não é "gente"; é um animal que, embora não adestrado, sabe respeitar quem é gente, os homens, os ricos.

Os recursos de discurso direto são poucos. As falas desse tipo são simples e reduzidas, como se a personagem quase não conseguisse se expressar linguisticamente. O silêncio e a precariedade da linguagem podem também ser marcas da posição-sujeito inferiorizada, subestimada - que Fabiano assume (ou é levado a assumir).

\section{$[\ldots]$}

- Ladroeira.

Nem lhe permitiam queixas. Porque reclamara, achara a coisa uma exorbitância, o branco se levantara furioso, com quatro pedras na mão. Para que tanto espalhafato?

- Hum! Hum!

[...] (RAMOS, 1995, p. 94).

Esses exemplos ratificam a complexidade do interdiscurso engendrado nos trechos de emprego do discurso indireto livre.

O discurso direto é um caso de heterogeneidade mostrada (AUTHIER-REVUZ, 2004), delimitando o que seria voz do narrador e o que seria das personagens. Já o discurso indireto livre em "Vidas Secas" vai, a nosso ver, além da heterogeneidade mostrada. Ele aponta as vozes do narrador e das personagens, de modo pouco claro, mas que, pela dubiedade, torna-se ainda mais fascinante, e, ao mesmo tempo, aponta os 
discursos sociais e históricos que constituem os sujeitos representados na ficção. A constituição do "eu" se dá pelo "outro". Os discursos alheios invadem ideologicamente o sujeito, que se subjetiva no interdiscurso, de modo fragmentado e heterogêneo, sem o controle da coerência. Isso permite refletir como Fabiano está assujeitado a discursos que o oprimem.

\section{CONCLUSÃO}

É comum, como apontado no início, tomar-se a leitura de textos não literários como um jogo de decifração, em que o leitor "encontra" o sentido que o autor, deliberadamente, desejou "colocar" em sua produção. Em textos literários, esse jogo se permite a um certo grau de variedade, como se apenas o texto literário contasse com a característica da opacidade da língua; logo, a leitura dessa espécie de texto poderia abrir espaço para a pluralidade de sentido.

Como a concepção de língua / linguagem incide diretamente no modo de trabalho com a leitura, entendemos que a leitura de textos literários e não literários desenvolvida nas escolas, comumente, ainda carrega preceitos teóricos limitados a uma visão de língua apenas como estrutura, sistema de signos que teria significação literal e imanente.

É preciso avançar no trabalho com a leitura, entendendo os textos literários e não literários como produtos da enunciação, num dado contexto histórico, que materializam discursos sociais e ideológicos. Esses sentidos não são originários de um sujeito; são resgatados pela memória discursiva e constituem os sujeitos - sempre sujeitos de linguagem - de maneira heterogênea, sem que se tenha controle deliberado sobre essa heterogeneidade.

Neste estudo, propôs-se uma leitura analítica, pelo viés da AD, da obra "Vidas Secas" e, mais especificamente, para a apresentação da análise, delimitou-se o capítulo "Contas". Observou-se a forma heterogênea e fragmentada segundo a qual a personagem Fabiano é engendrada, representando, por meio da mimese, muitos sujeitos-Fabiano pelo mundo. A análise aponta para reflexões acerca da condição subjugada e passiva desses sujeitos, que, muitas vezes, constituem-se por discursos da classe dominante.

Busca-se, com isso, contribuir para um modo de leitura que enverede para além da materialidade linguística, para além do escrito e descrito etnograficamente, e interprete os efeitos de sentido, o interdiscurso, a opacidade linguística que mascara a constituição dos sujeitos e suas filiações ideológicas. Essas leituras podem instigar discussões críticas com os alunos, de modo que se reflita sobre o texto, seus recursos linguísticos e estilísticos e, sobretudo, como esses recursos podem apontar para aspectos sócio-históricos que incidem sobre os sujeitos e a vida. 


\section{REFERÊNCIAS}

AUTHIER-REVUZ, J. Entre a transparência e a opacidade: um estudo enunciativo do sentido. Porto Alegre: Editora PUC-RS, 2004.

. Heterogeneidade(s) enunciativa(s). Trad. Bras. Cad. Est. Ling., Campinas, (19):

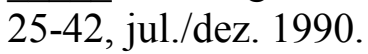

CORACINI, M.J.R.F. Leitura: decodificação, processo Discursivo...?. Em: CORACINI, M.J.R.F. O jogo discursivo na aula de leitura: língua materna e língua estrangeira. $3^{\mathrm{a}}$. ed. Campinas: Pontes, 2010. pp. 13-20.

CORREAA, M.L.G. Letramentos e gêneros do discurso na universidade. Incluindo discussão sobre (novas) práticas de leitura e escrita na internet. Em: ABREUTARDELLI, L.; KOMESU, F. (Orgs.). Letramento e gêneros: aproximações, distanciamentos. São Paulo: Editora da Unesp, 2016.

COURTINE, Jean-Jacques. Metamorfoses do discurso político: derivas da fala pública. São Carlos: Claraluz, 2006.

FOUCAULT, Michel. A ordem do discurso. 16a . ed. São Paulo: Loyola, 1996.

GARCIA, O. M. Comunicação em prosa moderna: aprendendo a escrever, aprendendo a pensar. 14ª . ed. Rio de Janeiro: Editora da Fundação Getúlio Vargas, 1988.

GREGOLIN, M. do R. Análise do discurso: os sentidos e suas movências. Em: GREGOLIN, M. do R.; CRUVINEL, M.F.; GAMA-KHALIL, M. (Org.). Análise do discurso: entornos dos sentidos. Araraquara: Cultura Acadêmica, 2001. p. 9-34.

ORLANDI, E.P. Análise de Discurso: princípios e procedimentos. $6^{\mathrm{a}}$. ed. Campinas: Pontes, 2005.

PÊCHEUX, Michel. O discurso: estrutura ou acontecimento. Trad. Bras. Campinas: Pontes, 1990.

III. Discurso e ideologia(s). Em: Semântica e discurso: uma crítica à afirmação do óbvio. Trad. Bras. Campinas: Ed. da Unicamp, 1988. p. 139-185.

PROENÇA FILHO, Domício. A linguagem literária. 8ª ed. São Paulo: Ática, 2007.

RAMOS, Graciliano. Vidas Secas. 70a . ed. Rio de Janeiro: Record, 1995.

SOUZA, Jessé. A tolice da inteligência brasileira: ou como o país se deixa manipular pela elite. São Paulo: LeYa, 2015.

TEIXEIRA, M. O “sujeito" é o "outro"? LETRAS DE HOJE, Porto Alegre, v. 32, n. 1, p. 61-88, março, 1997.

TERRA, Ernani. Leitura do texto literário. São Paulo: Contexto, 2014. 
UYENO, E.Y. A relação teoria-prática na formação continuada dos professores de línguas, a contradição como a negação da falta. Curitiba: Appris, 2012.

Memória e diáspora globalizada; a nova cartografia e a identidade múltipla do descendente do imigrante. Em: CORACINI, M.J.R.F.; GHIRALDELO, C.M. (Orgs.). Nas malhas do discurso: memória, imaginários e subjetividade, formação de professores (línguas materna e estrangeira), leitura e escrita. Campinas: Pontes, 2011.

\section{$* * *$}

Artigo recebido em: novembro de 2017.

Aprovado e revisado em: março de 2018.

Publicado em: maio de 2018.

\section{Para citar este texto:}

BARTHO, Viviane Dinês de Oliveira Ribeiro; SOUZA, Amanda Maria Bicudo de. Heterogeneidade discursiva do/no romance Vidas Secas: as vozes discursivas constituintes dos sujeitos-Fabiano. Entremeios [Revista de Estudos do Discurso, ISSN 2179-3514, on-line, www.entremeios.inf.br], Seção Temática [Discurso, arte e literatura - Parte I], Programa de Pós-Graduação em Ciências da Linguagem (PPGCL), Universidade do Vale do Sapucaí (UNIVÁS), Pouso Alegre (MG), vol. 16, p. 291-305, jan. - jun. 2018.

DOI: http://dx.doi.org/10.20337/ISSN2179-3514revistaENTREMEIOSvol16pagina291a305

\section{ANEXO}

\section{Trecho do capítulo de Vidas Secas analisado: "Contas"}

Fabiano recebia na partilha a quarta parte dos bezerros e a terça dos cabritos. Mas como não tinha roça e apenas se limitava a semear na vazante uns punhados de feijão e milho, comia na feira, desfazia-se dos animais, não chegava a ferrar um bezerro ou assinar a orelha de um cabrito.

Se pudesse economizar durante alguns meses, levantaria a cabeça. Forjara planos. Tolice, quem é do chão não se trepa. Consumidos os legumes, roídas as espigas de milho, recorria à gaveta do amo, cedia por preço baixo o produto das sortes. Resmungava, rezingava, numa aflição, tentando espichar os recursos minguados, engasgava-se, engolia em seco. Transigindo com outro, não seria roubado tão descaradamente. Mas receava ser expulso da fazenda. E rendia-se. Aceitava o cobre e ouvia conselhos. Era bom pensar no futuro, criar juízo. Ficava de boca aberta, vermelho, o pescoço inchado. De repente estourava:

- Conversa. Dinheiro anda num cavalo e ninguém pode viver sem comer. Quem é do chão não se trepa. 
Pouco a pouco o ferro do proprietário queimava os bichos de Fabiano. E quando não tinha mais nada para vender, o sertanejo endividava-se. Ao chegar a partilha, estava encalacrado, e na hora das contas davam-lhe uma ninharia.

Ora, daquela vez, como das outras, Fabiano ajustou o gado, arrependeu-se, enfim deixou a transação meio apalavrada e foi consultar a mulher. Sinhá Vitória mandou os meninos para o barreiro, sentou-se na cozinha, concentrou-se, distribuiu no chão sementes de várias espécies, realizou somas e diminuições. No dia seguinte Fabiano voltou à cidade, mas ao fechar o negócio notou que as operações de Sinhá Vitória, como de costume, diferiam das do patrão. Reclamou e obteve a explicação habitual: a diferença era proveniente de juros.

Não se conformou: devia haver engano. Ele era bruto, sim senhor, via-se perfeitamente que era bruto, mas a mulher tinha miolo. Com certeza havia um erro no papel do branco. Não se descobriu o erro, e Fabiano perdeu os estribos. Passara a vida inteira assim no toco, entregando o que era dele de mão beijada! Era direito aquilo? Trabalhar como negro e nunca arranjar carta de alforria!

O patrão zangou-se, repeliu a insolência, achou bom que o vaqueiro fosse procurar serviço noutra fazenda.

Aí Fabiano baixou a pancada e amunhecou. Bem, bem. Não era preciso barulho não. Se havia dito palavra à-toa, pedia desculpa. Era bruto, não era ensinado. Atrevimento não tinha, conhecia o seu lugar. Um cabra. Ia lá puxar questão com gente rica? Bruto, sim senhor, mas sabia respeitar os homens. Devia ser ignorância da mulher, provavelmente deveria ser ignorância da mulher. Até estranhara as contas dela. Enfim, como não sabia ler (um bruto, sim senhor), acreditara na sua velha. Mas pedia desculpa e jurava não cair noutra.

O amo abrandou, e Fabiano saiu de costas, o chapéu varrendo o tijolo, [...].

Foi até a esquina, parou, tomou fôlego. Não deviam tratá-lo assim. Diante da bodega de seu Inácio virou o rosto e fez uma curva larga. Depois que aconteceu aquela miséria, temia passar ali. Sentou-se numa calçada, tirou do bolso o dinheiro, examinouo, procurando adivinhar quanto lhe tinham furtado. Não podia dizer em voz alta que aquilo era um furto, mas era. Tomavam-lhe o gado quase de graça e ainda inventavam juro. Que juro! O que havia era safadeza.

- Ladroeira.

Nem lhe permitiam queixas. Porque reclamara, achara a coisa uma exorbitância, o branco se levantara furioso, com quatro pedras na mão. Para que tanto espalhafato?

- Hum! Hum!

Recordou-se do que lhe sucedera anos atrás, antes da seca, longe. Num dia de apuro recorrera ao porco magro que não queria engordar no chiqueiro e estava reservado às despesas do Natal: matara-o antes de tempo e fora vendê-lo na cidade. Mas o cobrador da prefeitura chegara com o recibo e atrapalhara-o. Fabiano fingira-se desentendido: não compreendia nada, era bruto. Como o outro the explicasse que, para vender o porco devia pagar imposto, tentara convencê-lo de que ali não havia porco, havia quartos de porco, pedaços de carne.

$\mathrm{O}$ agente se aborrecera, insultara-o, e Fabiano se encolhera. Bem, bem. Deus o livrasse de história com o governo. Julgava que podia dispor dos seus troços. Não entendia de imposto.

- Um bruto, está percebendo?

Supunha que o cevado era dele. Agora se a prefeitura tinha uma parte, estava acabado. Pois ia voltar para casa e comer a carne. Podia comer a carne? Podia ou não 
podia? O funcionário batera o pé agastado e Fabiano se desculpara, o chapéu de couro na mão, o espinhaço curvo:

- Quem foi que disse que eu queria brigar? O melhor é a gente acabar com isso.

Despedira-se, metera a carne no saco e fora vendê-la noutra rua, escondido. Mas, atracado pelo cobrador, temera do imposto e da multa. Daquele dia em diante não criara mais porcos. Era perigoso criá-los.

Olhou as cédulas arrumadas na palma, suspirou, mordeu os beiços. Nem the restava o direito de protestar. Baixava a crista. Se não baixasse, desocuparia a terra, largar-se-ia com a mulher, os filhos pequenos e os cacarecos. Para onde? Hem? Tinha para onde levar a mulher e os meninos? Tinha nada!

Espalhou a vista pelos quatro cantos. Além dos telhados, que reduziam o horizonte, a campina se estendia, seca e dura. Lembrou-se da marcha penosa que fizera através dela, com a família, todos famintos. Haviam escapado, e isto the parecia um milagre. Não sabia como tinham escapado.

$[\ldots]$

- Um dia um homem faz besteira e se desgraça.

Pois não estavam vendo que ele era de carne e osso? Tinha obrigação de trabalhar para os outros, naturalmente, conhecia o seu lugar. Bem. Nascera com esse destino, ninguém tinha culpa de ele haver nascido com um destino ruim. Que fazer? Podia mudar a sorte? Se lhe dissessem que era possível melhorar a situação, espantar-se-ia. Tinha vindo ao mundo para amansar brado, curar feridas com rezas, consertar cercas de inverno a verão. Era sina. O pai vivera assim, o avô também. E para trás não existia família. Cortar mandacaru, - aquilo estava no sangue. Conformava-se, não pretendia mais nada. Se lhe dessem o que era dele, estava certo. Não davam. Era um desgraçado, era como um cachorro, só recebia ossos. [...]

Na palma da mão as notas estavam úmidas de suor. Desejava saber o tamanho da extorsão. Da última vez que fizera contas com o amo o prejuízo parecia menor. Alarmouse. Ouvira falar em juros e em prazos. Isto lhe dera uma impressão bastante penosa: sempre que os homens sabidos lhe diziam palavras difíceis, ele saía logrado. Sobressaltava-se escutando-as. Evidentemente só serviam para encobrir ladroeiras. Mas eram bonitas. Às vezes decorava algumas e empregava-as fora de propósito. Depois as esquecia. Para que um pobre da laia dele usar conversa de gente rica? Sinhá Terta que tinha uma ponta de língua terrível. Era: falava quase tão bem como as pessoas da cidade. Se ele soubesse falar como Sinhá Terta, procuraria serviço noutra fazenda, haveria de arranjar-se. Não sabia. Nas horas de aperto dava para gaguejar, embaraçava-se como um menino, coçava os cotovelos, aperreado. Por isso esfolavam-no. Safados. Tomar as coisas de um infeliz que não tinha onde cair morto! Não viam que isso não estava certo? Que iam ganhar com semelhante procedimento? Hem? Que iam ganhar? [...] 